【論文】

UDC $: 72.03(52): 711.424: 728.81$
日本建築学会㖕画系論文報告集 第 412 号・ 1990 年 6 月 Journal of Archit. Plann. Environ. Engng, AIJ, No.412, June, 1990

\title{
園部旧城下町における町家遺構の発展過程と地方的特質 THE CHARACTERISTICS AND DEVELOPING PROCESSES OF THE TOWN HOUSES IN SONOBE, AN OLD CASTLE TOWN
}

\author{
大場 修* \\ Osamu OBA
}

\begin{abstract}
In this paper I explained the characteristics and the developmental process of the town houses in Sonobe, an old castle town by studying mainly the transformation of structures. : In addition. I considered the consequence by comparing the town houses near there with the farm houses around there. The summery of this study can be given below.

1) The front gabled town houses are relatively older than the side gabled town houses, and the original structural forms are the same as the farm houses in Settsu and Tanba area.

2) I realized that the side gabled town houses were derived from the front gabled town houses, because the structures of the side gabled town houses were similar to that of front gabled town houses.

3) Both front and side gabled town houses in an old castle town developed, being affected by the farm houses in Settsu and Tanba area.

4) I recognized that the form of the town houses in Sonobe, an old castle town was the form of the town houses in wide area including Kameoka, Yagi, and Syuchi.
\end{abstract}

Keywords : Town Houses, Old Castte Town, Form Houses,

はじめに

園部旧城下町は, 京都から近世の山陰道（中世以前は 篠山を経由していた）に沿って北西約 $30 \mathrm{~km}$ ，旧丹波国 に位置し，城郭や武家屋敷は殆ど旧規を留めないが，町 割や町家はよく残り, 現在も妻入と平入が混在する特有 の町並景観を留めている。

当町のように町屋敷地内において妻入と平入の異なっ た家屋形式が共存する場合，それ自体町並を特徵付ける 重要な特質であるだけに，両者間の関連性の有無とその 成立過程についての検討がおのずと課題となろう。

しかも亀岡, 篠山両旧城下町を始めとする旧丹波国(及 び旧攝津国）に所在する多くの町並も妻入と平入が混在 する同様の町並景観を構成していることから，これらの 地域にまたがる町家の共通性が予想される。しかも，こ の地域の町並は，妻入で縦割り型平面を特徴とする提丹 型農家の分布域に含まれることから（本稿第 6 節, 図一 21 参照), この地域の町家は摂丹型に繫ることも予想さ れる。

そこで本稿は，これまで建築調査が全く行なわれてい ない園部旧城下町を中心に取り上げ，園部旧城下町に残 る町家の発展過程を妻入, 平入別に検討したうえで, 両
者間の関係を求め, さらにその家屋形式の諸特徵につい て旧丹波国の旧山陰道に沿う周辺の町並における町家を 含めて検討し，さらに周辺農家との比較を通して，これ らの町家の祖形式について実証的な検討を加えた。

なお本稿は, 昭和 60〜61 年度に実施された京都府立 大学学術調查の一環として, 当時の林野研究室が担当し た当城下町の町家調查の結果に基づく研究である。この 調査結果は，既に 62 年 10 月に建築学会にその概要を報 告し ${ }^{1)}$ ，城下町の全貌と調査対象とした 39 棟の町家の 平面と構造の特質と変遷について概説した。また， 63 年には京都府立大学より出された学術報告書の中の一編 として調查結果の報告を行ない2), 上記論文を補足して， 内容の充実に努めた。本稿は, さらにその後の調査に加 え, 園部周辺の町家や農家の様相をも加味して検討を加 えたものである。諸先学のご教示とご叱正を賜れば幸い である。

\section{1. 園部城下町の概要}

園部城下町の成立事情については，既に竹岡林氏によ る研究がある3)。氏は，近世園部城は中世の園部城（天 正 6 年, 1578 , 明智光秀により落城）城跡を拡張して築 
城されたという見方が妥当であるとし，近世園部の城地 が中世の平山城を受け継ぐものであることを指摘した点 で重要である。

しかし，当城下町に関する都市史史料は必ずしも十分 ではないために，本稿では城下の町屋敷地に絞り, その 構成について概説するに留める。

園部藩の成立の経緯は，文化 2 年（1805）「略史前録 草案 $\left.\rfloor^{4}\right)$ からその一部が知れる。元和 5 年 (1619) 但馬 国出石城主小出信濃守吉親が 2 万 9 千 711 石で移封とな る。吉親の城郭普請は, 二重堀と塀を迴し, 城は天守の ない陣屋建てとした。このことは「近年園部城絵図 $ل^{5)}$ からもその様子を窥うことができる。吉親は城下町建設 に際し, 小向山北側を東流する園部川を大きく北側へ半 円形に迂回させて町場の用地確保と防御を計ったとい $う^{6)}$ 。このことは, 城下の東方を流れる大堰川の所々に その工事の一環だとされる「意閑堰」，「意䦥堤」(意䦥 は吉親の号である) が今日も残る゙ことからも推察でき る。

城下は, 宮町, 上本町, 下本町 (現本町), 新町, 裏 町 (現若松町), 大村町の 6 ケ町より成る(図一1)。園 部城北門 (釘貫門) から北, 本町筋との交差点（札の过 という）までの宮町には銀札所が置かれ，また，上本町 西端の木崎口から新町東端の小山口まで 8 町半 18 間半 の間には数か所の枅形が設けられていたという。この通 りは山陰道 (京街道) であることから, 城下の商業的中 心であると同時に，宿場としての役割も担っていた。ま た，街道筋の北側，園部川に沿う裏町は川沿いに「馬場」 「外倉庫」が配され，水運を利用した物資積出口として 賑った。

なお，大村町は城内の南背後に位置する。当町は城内 に隣接することから，町家に混じり下級武士の居宅も多 く建っていたのであるが, 現在は殆ど建て替わり，古い 町並は留めていない。

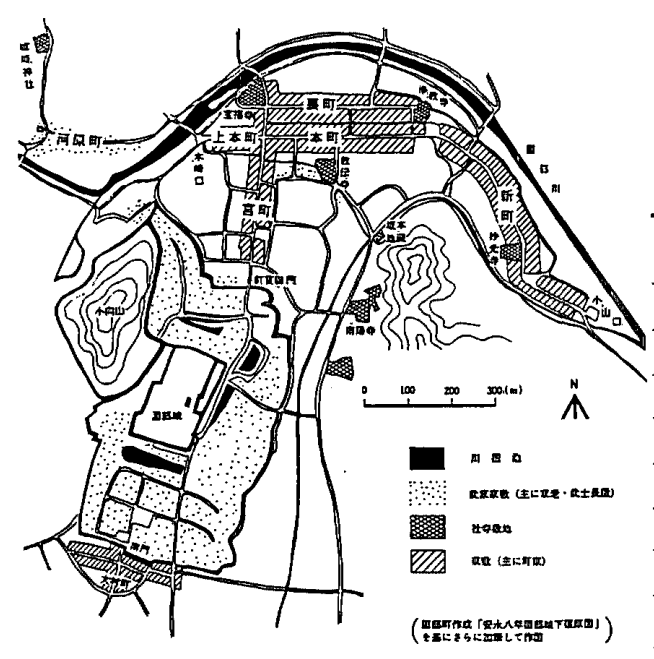

図一1 園部城下町復原図
城下の町並を具体的に知る史料は少ないが, 前出「略 史前録草案」には, 元和 5 年 (1619) 吉親の築城当時に おける侍屋敷の軒数をはじめ, 各町の間口総間数及び町 家総数が記されている。また, 元禄 13 年 (1700)「疄部 町大村町帳 $\rfloor^{8)}$ (以下「元禄町帳」と呼ぶ), 级び安永 8 年 (1779)「園部町, 大村町家別間口改帳」9) (以下「安 永改帳」と呼ぶ) などは，いずれも各町ごとに町屋敖の 間口, 奥行幅, 所有者名が記録されているこょから, 近 世中期の屋敷割, 町家規模がおおよそ分かり, かつ沅和 から元禄にかけての, 近世初期の城下の町屋敖数の推移 もある程度窅える。

それによれば, 元和 5 年の町家総数は 430 軒であるが, 元禄 13 年には 454 軒になる。また「元禄町帳」に上る 明和 3 年改めの総家数は 486 軒とさらに増え, 5 年後の 「安永改帳」も 484 軒とほぼ一致する。築城から 18 世 紀後期にかけ, 町家は一定の增加率で少しづつ増加し続 けたといえる。

また,「元禄町帳」,「安永改帳」からは当侍の町屋敷 の間口幅の傾向が分かるが, 表一1 は大村町を除く 5 町 内における町屋敷地の間口幅 (元禄, 安永共に 1 間 : 6 尺 3 寸棹で検地）を両史料で比較したものである。いず れも間口幅 3 間が最多で, 3 間半から 5 間半末満の町家 がそれに続き， 2 間に満たないものから 5 間半幅までの 町家をあわせると, 元禄 13 年では総数の約 $72 \%$ であ り,さらに安永 8 年では約 $81 \%$ に達する。すなわち, 大半が中規模以下の間口幅の屋敷地で構成されていて, これらは町ごとに差はあるものの概して増加の傾向にあ ることが分かる。逆に，5間半以上の比較的間口幅の広 い町屋敷地は, 元禄から安永にかけて減少するが, 家総 数は増加する。つまり，この間に間口幅 5 間半以上の大 きな屋敷地を持つ町家が細分化され，殆よ゙が間口幅が 3 $\sim 5$ 間半に小規模化された結果と推察される。

当時の町並景観の樣子を知ることは困難であるが, 員 原益軒の紀行文「西北紀行」(元禄 2 年, 1689 ,「諸州巡 覧記」所収）には，園部について僅かながら「園部は鳥 羽より一里あり, 小出伊勢守殿在所なり, 町長く民家良

表一1 元禄一安永, 町屋敷地の間口幅比較表 
からず，京より九里，これより西に篠山あり，但馬へゆ く道なり」と記され，当時の町並が，京都などと比べか なり見劣りする状況であったことが想像される。

なお, 近世後期の園部は, 海保青陵が文化 10 年 (1812) に著した「稽古談」(10)に「丹波ノ園部八二万石ノ処也， 京二近キ処工エ二京（屋）敷アリ（中略）京都屋鋪二ヨ イテ園部ノ産物ウリサバキト云コトヨ始メテ御勝手向乇 是二准ジテ今八段々トンデキタル由也」とある如く，恵 まれた水陸交通路により，京都との物資の交流が頻繁に 行なわれたことも, 後節において, 町家の発展過程を考 察する際の背景として指摘しておく。

\section{2. 町家遺構の編年}

町家調查は，旧城下（町家遺構を残さない大村町を除 く各町）の全遺構に対する予備調查を経て, 変遷過程を 知るうえで重要と判断された遺構 36 棟につき復原調査 を行なった。また，当町では幸いにも鬼瓦銘の残る遺構 が数多く発見されたのでその採取に努め, 復原調査遺構 の年代判定の史料としたが，当然転用の可能性もあるの で注意を払った。

調查遗構の最古は, 寛延 4 年. (1751, 系図の写しより) の妻入形式の片山弘家住宅 (本町) であり, 平入町家で は天明 5 年 (1785, 鬼瓦銘より) の杉森亮侶家住宅（上 本町）が最古で，この 2 棟を含め 18 世紀に遡ると考え られる遺構が 8 棟（内 7 棟の年代が判明）にのぼった。 また，そのうち 5 棟は妻入町家であることから, 調査し た妻入遺構 11 棟の約半数が 18 世紀に遡ることになり,
現存遺構のなかで, 妻入町家は平入町家より相対的に古 いことが推察された。

さて復原した町家遺構を年代判明遺構を基準に; 座敷 飾りの諸装置の有無, 柱間装置の種別, 床, 棚, 押入な ビの居室上手に造り付げられた諸装置の奥行幅, 析高 (表 裏とも), 2 階の状態, 2 階座敷の有無, 構造形式 (後述) などを指標として編年し, 妻入, 平入別に年代順に配列 した。さらに上記編年指標の推移に基づき，妻入，平入 別にそれぞれ同じ発展段階と見なせる遺構群をグルーピ ングすることにより (妻入を 3 期, 平入を 4 期に分けた。 その経緯については後述する), 発展過程を年代区分し た (表-2)。

なお, 平面は全て通り庭形式で, 居室は $1 \sim 2$ 列に 2 ～8 室を配する。これを型別に居室数に応じて II 〜㚼型

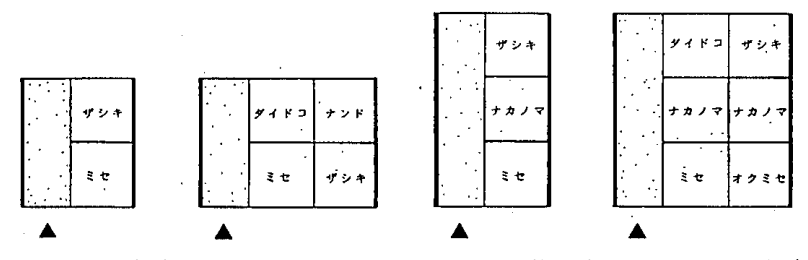

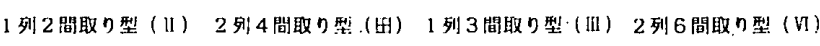

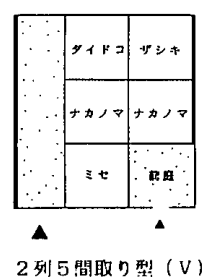

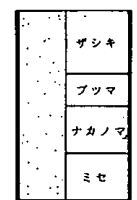

$\Delta$

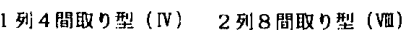

図一2 平面形式模式図
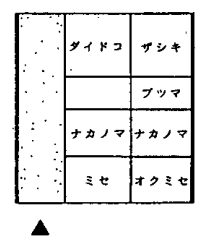

表一2 園部旧城下調查遗構編年表（妻入, 平入別）

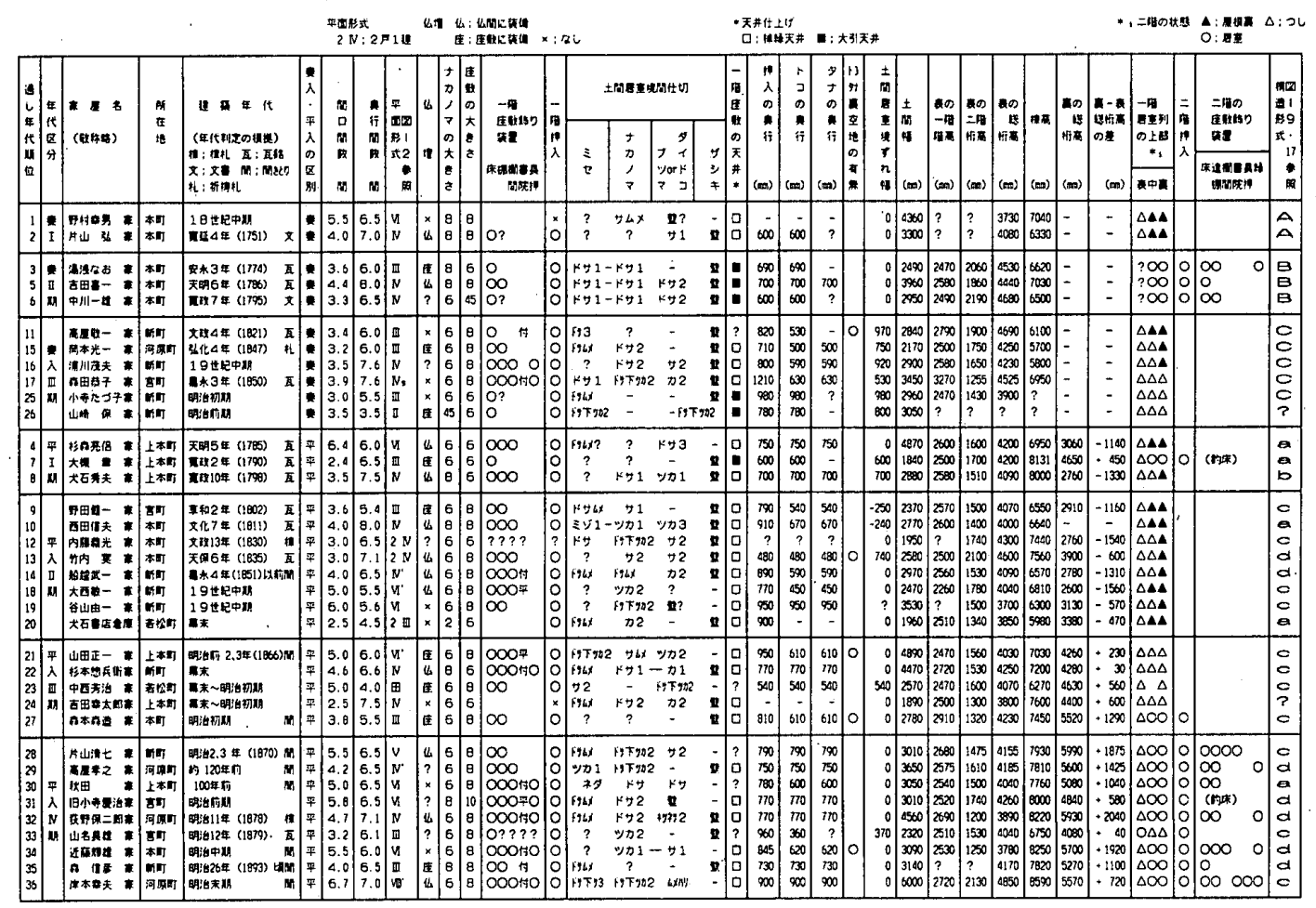


の 7 種に分類し，図一 2 に表示した（表一 2 の記号と同 じ)。

以下，妻入，平入別に，まず各年代の発展段階におけ る形式的特徵を良く示す代表遺構について概説し，各年 代の諸特徴を求めた上で, 平面 ·構造上の発展過程を検 討する。さらに，後節ではこれら町家の形式及びその発 展過程を，特に構造に注目しつつ周辺町家及び農家との 関連において再考し，その地方的位置付けについて言及 する。

\section{3. 妻入町家の平面, 構造と発展過程}

\section{3-1＼cjkstart妻入町家の代表遺構}

1) 野村幸男家住宅（本町，18 世紀中期，図一3)

居室廻りが著しく改造を受けたため柱間装置は不明を 多く残すが，妻入で 2. 列型は当家住宅のみであり，しか も居室上手に諸装置が無く壁のみである点は，妻入の割 に大きい間口幅を勘案すると, 以下で述べる他の遺構に 比べ一段と古式である。構造は，長い梁行の小屋梁の上 に和小屋を組み，土間居室境，土間，居室各上部の計 5 本の桁行梁がこの小屋梁を受け，さらにその下に梁行梁 を渡す。ちょうど桁行梁を二重梁で挟む複雑で念入りな 方式をとる。なお，2 階は表のみに低いツシを設けるだ けである。

以上, 当家住宅は居室上手に装置が無く, 2 階は和小
屋の屋根裏で, しかも桁高が低く材も古いことを考慮に 入れると, 次に述べる片山弘家住宅と比べて古風であり， 妻入最古の遺構と考えられる。

2) 片山弘家住宅（本町，寛延 4 年，1751，家系図の写 ᄂ, 図-4)

居室回りの改造のため, 当家住宅も平面の詳細は不明 ながら, 1 列 4 間取り型で, 居室上手には既に林, 棚(？）， 仏壇, 押入の諸装置が並ぶ。しかし座敷に欄間, 書院: 長押等は設けず，また居室上手の諸装置の奥行幅も 60 センチで遺構中最小幅である。析高は低く,ツシ 2 階は ミセ上部に設け, 他を和小屋の屋根裏とするなど野村家 住宅と同様古風であるが, ナカノマ上部の一部に登り梁 （1本）を架けて母屋を受け, 土間から物置として使え るような配慮もみられる。構造は, 梁間が短いため桁行 梁は 3 本であるが，基本的には野村家住宅と同じと認め られる。従って, 両家住宅の構造は 18 世紀中:期の妻入 町家の典型として注目される。

3) 吉田喜一家住宅 (本町, 天明 6 年, 1786, 鬼瓦銘, 図-5)

この遺構も 1 列 4 間取りで, 押入など諸装置の奥行の 浅さ (70センチ) は片山家住宅と良く似ている。また， 土間居室境を胴差の 1 本溝（但し戸袋なし）とする手法 は古式であるが，ミセ，ナカノ文間を通して長く 1 本溝 とする方式は, 他にも湯浅なお家住宅 (本町, 家永 3 年,

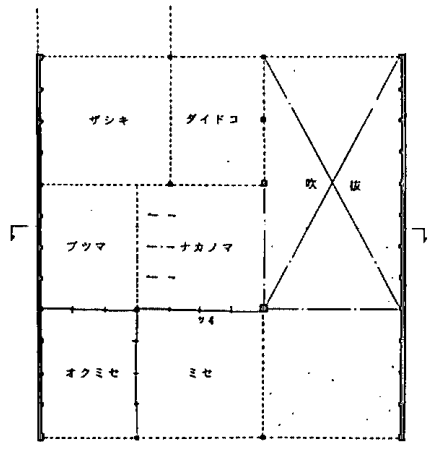

$\Delta$

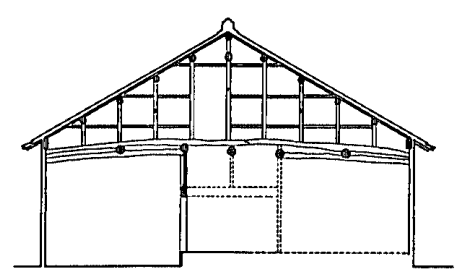

図一3 野村幸男家住宅（妻入）復原平面図, 復原断面図

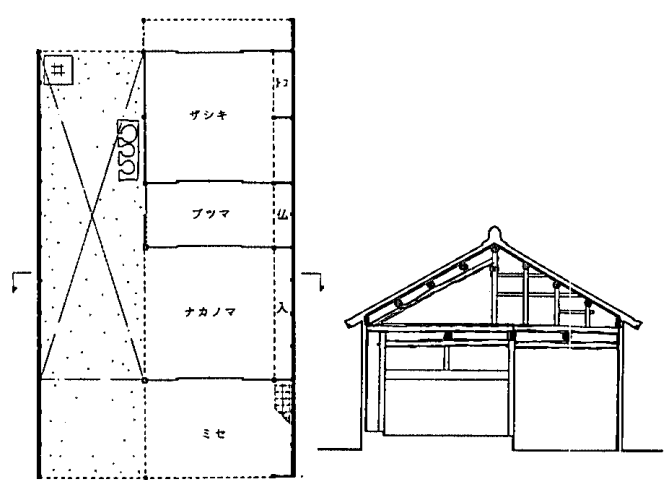

図一4 片山 弘家住宅（妻入）復原平面図, 復原断面図
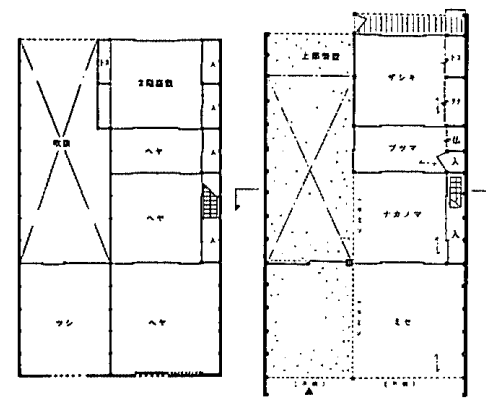

1 路

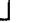

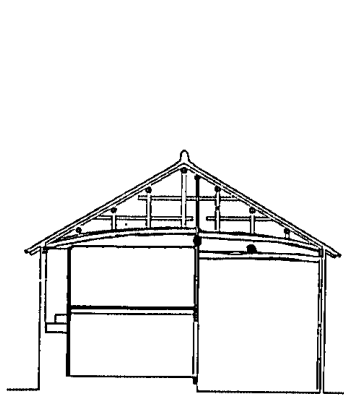

1

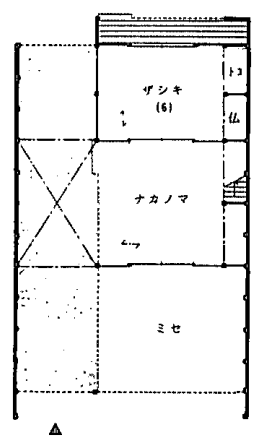

图一6 湯浅なお家住宅（妻入） 復原平面圂

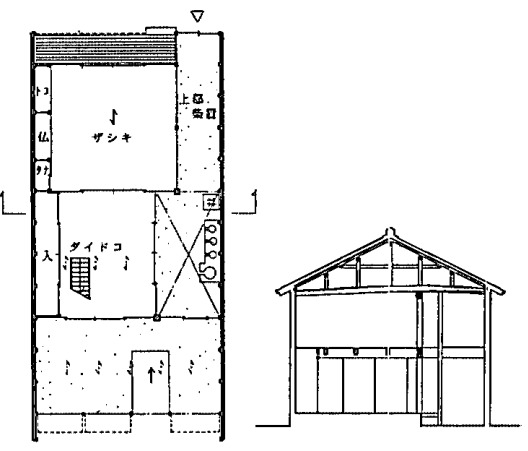

$\Delta$

図一5 吉田喜一家住宅 (妻入) 復原平面図, 復原断面図

図一7 岡本光一家住宅 (妻入) 復原平面図, 復原断面図 
1774, 鬼瓦銘, 図一6), 中川一雄家住宅 (本町, 寛政 7 年, 1795, 家系図写しょり) など, ほぼ同時代の町家に 共通して認められる。

構造は，土間上部は片山弘家住宅と同じであるが，居 室側は小屋梁のみで梁下にすぐ棹縁天井を張り低い 2 階 居室を設ける('そのため階下の 1 階座敷は大引天井とな る，表一 2 参照)。つまりこの構造は， 2 階居室を設ける ために片山家住宅の架構の一部が省略された形と見なせ よう。このような居室上部の 2 階居室も, 湯浅, 中川両 家住宅に共通して認められ, かつその構造も当家住宅と 同様である。

4) 岡本光一家住宅 (河原町, 弘化 4 年, 1847, 祈㿧札, 図一7)

1 列 3 間取り型の平面は, ミセを土間とし, 居室列が 土間境で食い違う。ミセを土間とする遺構は珍しく, 当 家住宅だけで確認された。恐らくは家業との関係が予想 されるが, 当初の家業は不明でその理由は明らかにし難 い。また，仏壇は座敷に設けられている（床，仏壇，棚 と並ぶ)。仏壇の位置, 換言すれば専用の仏間の有無に ついては，例えば同じ 1 列 3 間取り型の湯浅家住宅（安 永 3 年, 1774 , 図一6 参照) も座敷に仏壇を配するよう に, 1 列 3 間取り型では座敷は仏間を兼ねることが多い。 専用の仏間を設ける点が 1 列 4 間取り型との平面上の違 いであることが窺える。

構造は, 梁行に 1 本の小屋梁を架け, 土間居室境の桁 行梁がそれを受ける単純な構成が特徵である。また, 2 階に居室を設けない点も前記吉田家住宅等と異なる。そ のためか，座敷は同家住宅などとは異なり棹縁の釣り天 井とする。従って，これは 1 階座敷の書院座敷化を図る 前提条件となる構造と見なせ，事実，次に取りあげる森 田恭子家住宅にこの形式は引き継がれ，書院座敷化が格 段に進む。

なお，この構造による早い遺構例は文政 4 年 (1821, 鬼瓦銘）の高屋敬一家住宅である。ただし，当家住宅は 後に居室上部の梁を切断して高く持ち上げ，その下に 2 階居室を増設したため，現状は当初の形状を留めない。 5）森田恭子家住宅（宮町, 嘉永 3 年, 1850, 鬼瓦銘, 図-8)

岡本家住宅と基本的には同様の構造をもち，2 階居室 を設けない。また, 座敷飾りが付書院, 長押を含出揃 い，押入の奥行も梁い。この時期の妻入町家は， 2 階の 居室化より 1 階の書院座敷化を優先する傾向が読み取れ よう。

\section{3-2 妻入町家の構造類型之年代区分}

妻入を代表する上記 5 遺構の構造は，野村・片山両家 住宅, 吉田家住宅, 岡本・森田両家住宅の 3 グループが 互いに区別されるべき特徵を備え, かつ年代的にも並び うる関係にある。現存する他の妻入遺構の構造もいずれ

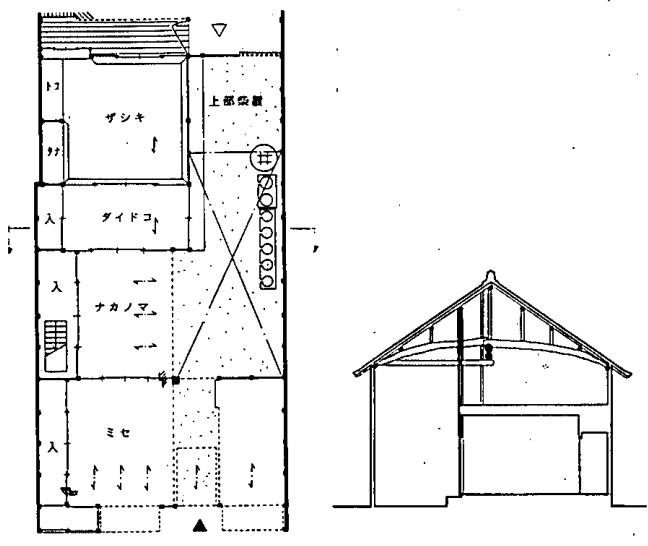

図一8、森田恭子家住宅（妻入）復原平面図, 復原断面図

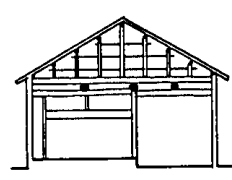

A 型U

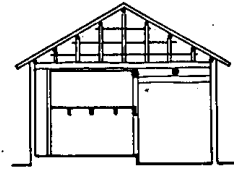

B 파니

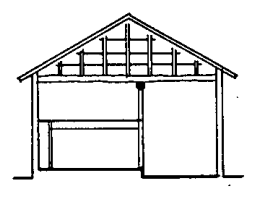

C 型
図一9 妻入町家構造類型

かに属することから, 上記 3 グループの構造を妻入町家 の代表的構造類型と位置付け,便宜上それぞれを A 型(野 村·片山両家住宅), B型 (吉田家住宅, 他), C型 (岡 本・森田両家住宅，他）上仮称する（図一9)。

しかも 3 種の構造類型は, 最古の野村家住宅 ( $\mathrm{A}$ 型) を筆頭に, $\mathrm{A}$ 型：18 世紀中期以前, $\mathrm{B}$ 型：18 世紀後期, C 型：19 世紀前期以降に各々対応し, 結果的に構造の 発展過程を 3 期に大別できる(表一 2 参照)。さらに妻 入 $\mathrm{A}$ —C 型の発展過程は, そのままそれぞれが妻入町 家の異なった段階に対応するとみなしうる。

そこで, 野村・片山両家住宅の 18 世紀中期以前を妻 入 I 期とし，B型が確認できる湯浅家住宅より中川家住 宅までの 18 世紀後期を妻入 II 期と考え，さらにC型の 高屋敬一家住宅以後の 19 世紀前期以降を妻入正期とみ なした。

\section{3-3 妻入町家の発展過程}

I 期は 18 世紀中期以前の古形式を, 野村家住宅は平 面と構造に, 片岡家住宅は構造になお留めた段階と理解 できよう。以下の各期の変遷過程は構造の単純化, 簡素 化の過程であると同時に, II 期は 2 階の居室化が特徵と して指摘でき，四期では 1 階座敷の書院座敷化が注目さ れる。II期は，2 階に居室を設けるために 1 階座敷天井 は大引天井となるためか, その書院座敷化は進展せず, 四期では座敷上部が逆に屋根裏（あるいはツシ 2 階）と して座敷に棹縁天井を釣り, 座敷の書院座敷化が著しく 進む。

なお, 妻入町家は明治以降も建て続けられ, 遗構も数 棟現存している。これらには予備調查の段階でも 2 階の 居室化等が看取され，いわば妻入 $\mathbb{N}$ 期に相当する発展段 
階が想定された。しかし今回の調査研究では, 種々の制 約からこれら遺構を詳しく調査ができなかったため,や むなく割愛した。

\section{3-4 妻入町家の平面構成}

次に, 妻入町家の平面に注目し, その年代的変化を検 討する。

I， II 期の遺構のナカノマと座敷の大きさを比較すれ ば, ナカノマは殆ど 8 畳であり, 座敷より広いか同じ広 さである (表一 2 , 図一 $3,4,5,6$ 参照)。I，II 期の來 敷は座敷飾りが無いか不揃いであり，むしろナカノマが 生活の中心として相対的に重視されているように思え る。それが四期になると両者の関係は逆転する。而期で は書院座敷化が進み, ナカノマから座敷へと居室構成の 重心が移動する。四期に集中する食い違い型間取りは, 座敷をナカノマよりも広くとる（6畳のナカノマに対し て座敷を 8 畳とする) 結果であると推察される。

なお，居室上諸手装置の奥行幅は，I 期の片山家住宅 が最小幅であるが，II期においても余り変化がみられな い(押入，床，棚共に同寸法）。期に至り，幕末から 明治初期にかけて押入の奥行幅はようやく約半間幅とな る。つまり, 年代が下るに従い奥行幅を増す傾向はおよ そ窥えるのであるが, その奥行幅は概して浅く, かつ遺 構ごとにまちまちで不揃いであることも知られた。

\section{4. 平入町家の平面, 構造と発展過程}

\section{4-1 平入町家の代表遺構}

平入町家についても，まず各期を代表する遺構につき 概説する。

1) 杉森亮侶家住宅 (上本町, 天明 7 年, 1785 , 鬼瓦銘, 図-10)

平入最古の遺構例である。間口幅の広い 2 列 6 間取り 型であるが，土間廻りと土間沿い居室が大幅な改造を受 け, 不明な点の多いのは惜しまれる。上手居室列は床, 棚に欄間が揃い, 同時期の妻入町家より書院座敷化がや や進んでいる(これは間口幅の違いから想起される階層 的な違いなのかもしれない)。また，居室上手諸装置の 奥行幅が間口偪の長さにもかかわらず 75 センチと浅い
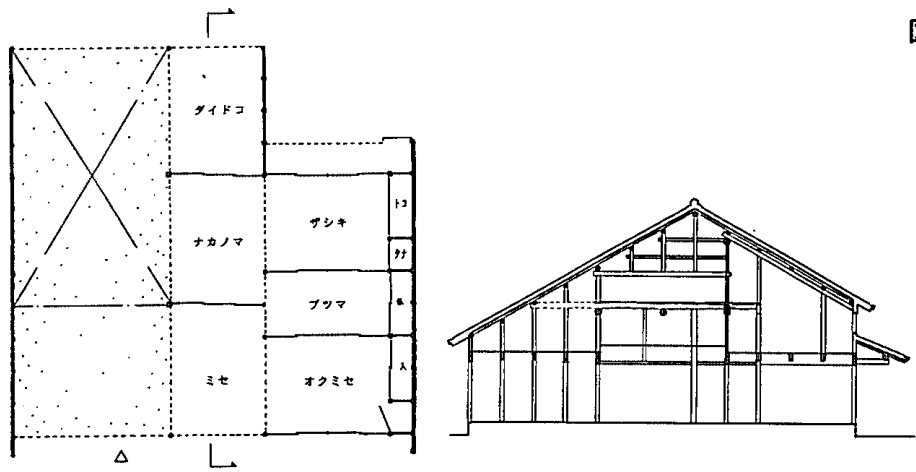

图一10 杉森亮侣家住宅 (平入) 復原平面図, 復原断面図)
こ.とは, 妻入 I ，II期の片山，吉田両家住宅 (70 センチ) に類似する。

構造は, ミセ上部は登り梁を架けてッシ 2 階とし, ナ カノマから裏手は表裏に長い梁を二重に渡し, 上部を泪 小屋とする。下方の梁は長い桁行梁 (牛梁) で支持され る。二重梁で棟を高めているために，大屋根は滖手に長 く苜き降ろすことができ，表裏に居室が深くとれる。こ の家は，ミセ上部をツシとする以外は，他の居室上部を すべて屋根裏とすることは古式といえる。

2）犬石秀夫家住宅 (上本町, 寛政 10 年, 1798, 鬼瓦銘, 図-11)

1 列 4 間取り型のこの町家は, 仏間と座敷の上手のみ に装置を設け，他は壁のみとする点や，土間居室境を戸 袋付き 1 本溝とするなよ゙, 平面構成は古風である。また 上手の装置すべての奥行幅が 70 センチと浅い点も，非 森家住宅,さらには同時期の妻入遺構と同じ傾向を示す。

構造は，表を登り梁でッシ空間とし，裏方は前記杉森 家住宅のように二重梁とせず，小屋梁は表桁高より高い 位置に 1 本のみとし，ナカノマ上部にも空間（ツシ）を 造ることが可能となった。しかし，この小屋梁は 2 本の 牛梁と地棟で挟まれていることは，杉森家住宅よりも複 雑である。また，座敷，カマヤ上部は錣状に屋根を降乃 す点も杉森家住宅と異なる断面形状である。

3）野田健一家住宅（宮町，享和 2 年，1802，鬼瓦銘， 図-12)

平面で注意すべきは，土間居室境の食い違い方であろ う。前記遺構のような座敷を土間方に突き出す食い違い 方とは異なり，この家は逆に座敷を引き込んでいる（表

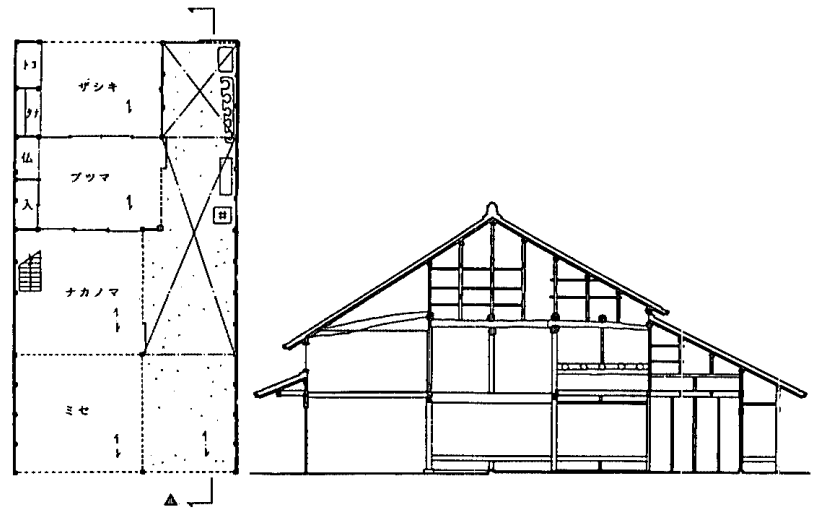

図一11 犬石秀夫家住宅 (平入) 復原平面図, 復原断面図

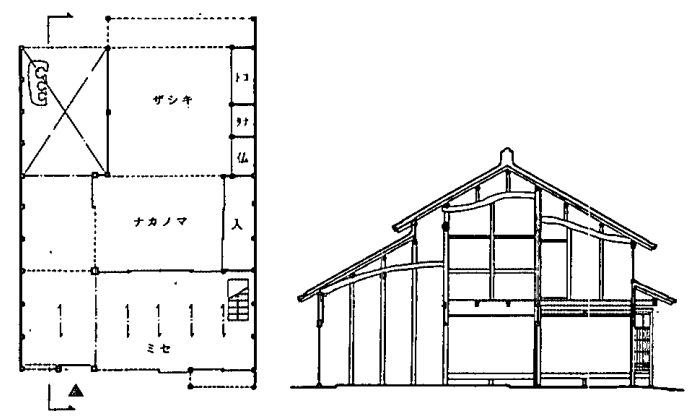

図一12 野田健一家住宅（平入）復原平面図，復原断面図 
一2ではこのようなずれ偪をマイナスで表示した)。こ れはナカノママの押入れを間中（半間）と深くしたため， 座敷の床，棚の奥行 (これは深くする必要がない) との 差の分だけずれが生じ，結果として土間の裏方のクド廻 りが広くなったものと考えられよう。また，食い違う箇 所には柱（通し柱）が省略されずに建つ点は，前記犬石 家住宅と共通する（次の遺構では，その省略化が認めら れる)。

さて，構造は，前記までの平入町家の特徴であった桁 行, 梁行の長い梁は共になく, 主要な柱は全て母屋まで 通する新しい形式をとる。当家住宅は，この形式をとる 遺構のなかでは最古である。

4) 西田信夫家住宅 (本町, 文化 7 年, 1811 , 鬼瓦銘, 図-13)

土間居室境の食い違い形状は野田家住宅と同じではあ るが，食い違い箇所の柱の省略は野田家住宅より一歩進 んだ方式とみなせよう。断面形状は, 裏手 2 室を角屋之 する点に特色があるが，これは当家住宅のみであった。 しかし，大黒柱を通し柱とせずに桁行梁を支持しその上 に長い梁行梁を渡す構造は野田家住宅とは異なり,むし ろ杉森家住宅の梁行梁と析行梁との構成に似ている。

5）船越武一家住宅 (新町, 嘉永 4 年, 1841 頃, 図一14)

この遺構も構造に特徵がある。長い梁行梁を土間居室 境上部に通す点は，裹手の大屋根を長く苗降し，居室裹 手上部を屋根裏とすることと併せて杉森家住宅との共通
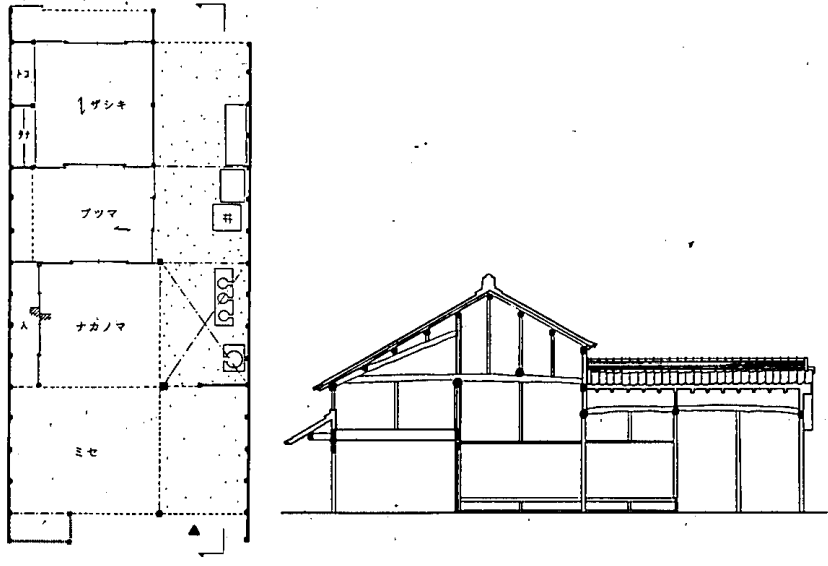

図一13西田信夫家住宅 (平入) 復原平面図, 復原断面図

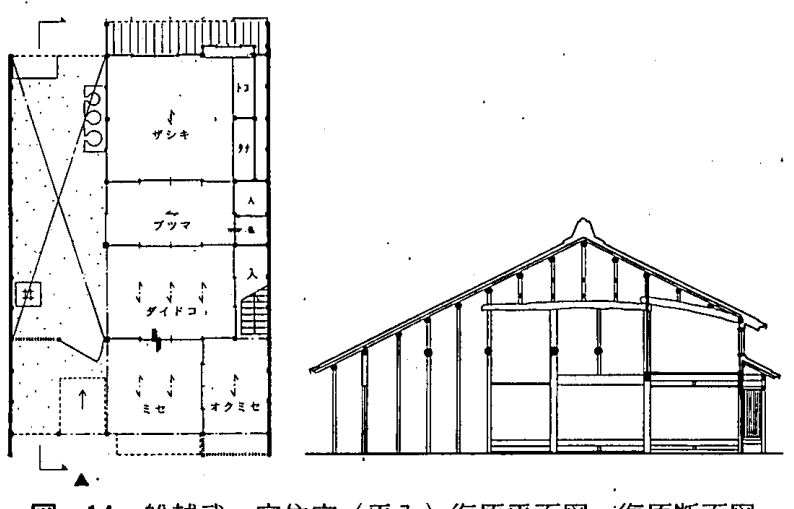

図一14 船越武一家住宅 (平入) 復原平面図, 復原断面図
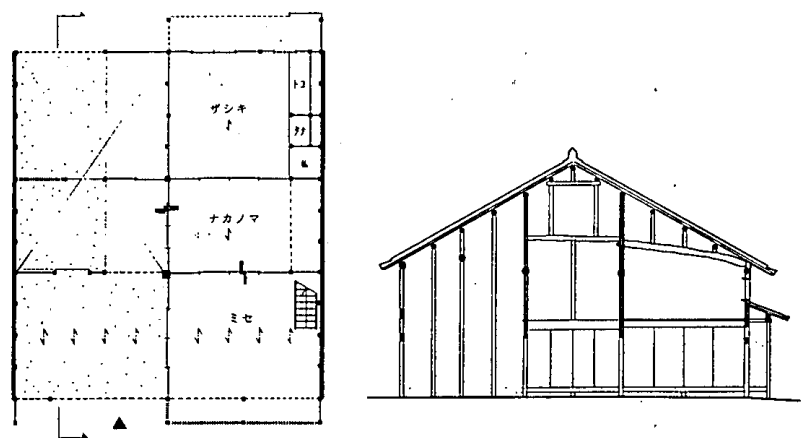

図一15 山田正一家住宅 (平入) 復原平面図, 復原断面図

性が窅える。しかし，梁行梁を受ける析行梁 (牛梁) を 持たない点は杉森家住宅と異なり，より簡略化されてい る。また居室上手の装置の奥行幅は 89 センチとほぼ半 間に近く，しかも床，棚の奥行だけを浅くする点は上記 までの遺構には無い新しい傾向である。当家住宅以後, 野田, 西田両家住宅のような食い違いは認められなくな る。

6）山田正一家住宅 (上本町, 明治 2,3 年前, 図一15) この遺構で注目されるのは，断面の構成である。構造 は野田家住宅と同様の形式をとるが，裏手の析高が野田 家住宅や船越家住宅より高くなり，それに伴い裏手を含 む居室上部がすべてッシ 2 階となる。

7) 片山清七家住宅 (新町, 明治 2,3 年, 図-16)

2 列 5 間取り型で, 前庭をとる平面形式はこの遗構だ けである。この家の特徴もやはり断面構成にある。つま り, 裏手の析高が表に比べ著しく高く, 2 階には裏手に 2 階座敷を設けるなよ゙，居室化の進行が注目される。

\section{4-2 平入町家の構造類型}

以上の平入 7 遺構を構造の類似性に注目して分類する と, 杉森 - 西田両家住宅, 犬石家住宅, 野田 - 山田・片 山清七各住宅, 及び船越家住宅の 4 種となろう。

他の平入遺構の構造も以上 4 種のいずれかに属するこ とから，これらを平入の代表的構造類型と見なし， $\mathrm{a}$ 型 (杉森家住宅, 他), b 型 (犬石家住宅), c 型 (野田家 住宅, 他)，d 型 (船越家住宅，他）と仮称する (図一17)。

これらを相互に比較すると，まず $\mathrm{a}$ 型と $\mathrm{b}$ 型は類似 性が強い。なかでも b 型は最も複雑な形式であり, $\mathrm{a}$ 型 はb 型がもつ二重の桁行梁 (牛梁)を 1 本とした構成 亡見なせよう。一方，c型はすべて通し柱で構成され， 上記 $\mathrm{a}, \mathrm{b}$ 型のいずれとも関連が認め難い独自の構造形 式である。逆に, $d$ 型は $a, b$ 型との関連性を示し, 具 体的には $\mathrm{a}$ 型から桁行梁を抜き，梁行梁のみとする簡略 化が進んだ形式と受け取れる。

\section{4-3 平入町家の年代区分と発展過程}

18 世紀後期から 19 世紀前期の平入町家は，鬼瓦銘な ビから年代が明確な遺構が多い。幕末から明治期の遺構 は鬼瓦銘の習慣がなくなるのか, 年代の判定史料にそし いが，この時期になれば聞き取りでもおよその年代が判 


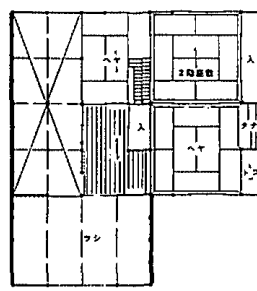

2 暗

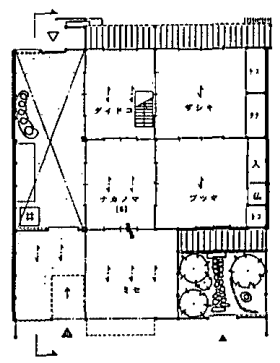

1 陼

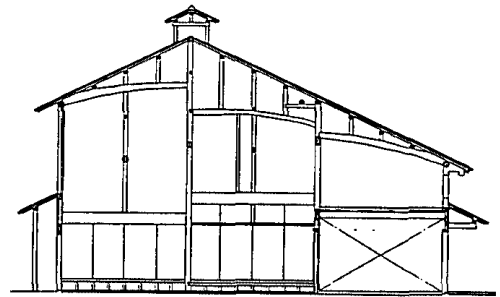

図一16 片山清七家住宅 (平入) 復原平面図, 復原断面図

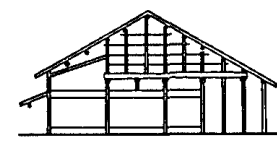

a 堽

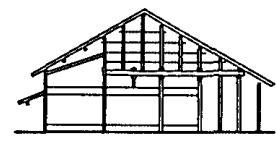

b 표리

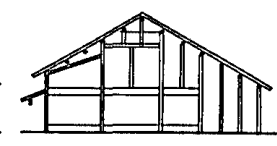

$C$ 些品
图-17 平入町家構造類型

断できるため，これらを年代順に並へ，以下平入町家の 平面, 構造の変化を検討した（表一2）。

杉森, 大譛章 (上本町, 寛政 2 年, 1790, 鬼瓦銘), 犬石各家住宅は，平面，構造共に取り立てて区別できな い（但し，大梘家住宅は，2 階に居室を設ける点が異質 であるが, 当期及び続くII 期においても 2 階居室をもつ 遺構は他に認められず，当家住宅はむしろ特例と見なし たい。調查遺構中最小の間口幅故であろうか)。しかし ながら, 続く野田家住宅は上記 3 遺構の構造と区分され るべき $\mathrm{c}$ 型の遺構であり，以下この構造が多く認められ ることから，犬石家住宅までを平入 I 期 (18 世紀後期) とみなし，野田家住宅以降を平入 II 期と考えた。

$\mathrm{I}$ 期の平入遺構は $\mathrm{a}, \mathrm{b}$ 型構造をもち, 平面は居室上 手の装置の奥行幅が同期の妻入町家と同様に浅い。しか し，杉森家住宅の間口幅のゆとりから勘案すれば，この 奥行の浅さは敷地間口幅の制約ではなく，むしろ 18 世 紀に遡る妻入, 平入両遺構に共通する平面上の特徵とみ なしえよう。また座敷が 6 畳で，ナカノマと同じか小さ いという傾向も同時期の妻入遺構と共通する。

II 期は 19 世紀前期一中期に属する。構造は $\mathrm{c}$ 型が多 $<, a$ 型も残り $\mathrm{d}$ 型も併存する。同期の遺構は座敷が殆 ど 8 畳となり座敷飾りも揃ってくる。しかし, 裏手桁高 はなお低く，裏手居室上部は屋根裏のままである。

続く明治 2,3 年前の山田家住宅は裹手桁高が表より 高まり, 居室上部は全面ツシとなる。このような形状を, 平入町家における 2 階の居室形成に至る過渡的な段階亡 位置付け, 同家以降を平入囵期 (幕末一明治初期) とし, 2 階が未発達な II 期と区別した。四期を通して裏析高は 漸次上昇し, 森本森造家住宅 (本町, 明治前期) では妳 高の表裏の差が 1 メートルを越え， 2 階に居室ができる。 (表一2「裹一表総析高の差」の項参照)。平入町家の 2 階は, 裏桁高の増加と呼応しつつ形成されたことが確認

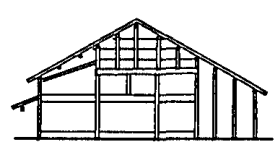

a 필
された。

また四期では，杉本惣兵衛家住 宅（新町，幕末期）にて曼押が揃 い, 座敷飾りが完備される。座敷 飾りが出揃う時期は妻入朾家とほ ぼ同時期である。

さらに片山清七家住宅では裏析 高が一段と高まり, 座敷師りを備 えた 2 階座敷が成立している。2 階座敷の成立をもって平入町家の 新段階と見なし，当家以降を平入 IV期（明治以降）とした。当期は 裹手桁高が十分に高く，また 1 階 座敷， 2 階座敷共に座敷飾りが揃 い, 平入町家の完成期とみなせ上 う。

しかし，表析高に注目すれば，逆に目立った上昇は認 められない。事実, 表側 (ミ七上部等) は居室化がなさ れずッシ 2 階のままで明治末期に至る（表一 $2\lceil 1$ 階居 室列上部」の項参照)。換言すれば，2 階の居空形成に もかかわらず，中 2 階建の外観が明治末期まで強く墨守 されたといえる。

\section{5. 妻入と平入の関係}

前節では, 妻入と平入別に平面, 構造の特徵と発展過 程を明らかにしたが,では平面, 構造の諸特徵は妻入, 平入の違いと如何なる関係にあるのだろうか。以下で考 察する。

まず，調查遺構の平面形式及び規模と，妻入，平入の 違いとの関係について検討した(図一18)。奥行方向では， 奥行の梁い 4 室型町家が妻入，平入共にみられ，奥行幅 に両者の違いは認め難い。また間口幅も妻入に少数なが ら 2 列型事例（野村幸男家住宅）が存在するため，間口 幅 5 間半以下の範囲では，平入に対する妻入独自の間口 幅領域を限定することは難しく，5間半を越える大型間 口の町家について，初めてその殆どが平入であるといえ る。

つまり, 間口 5 間半以上の大型町家を除けば, 妻入, 平入相互の平面規模には特記すべき違いは認められず, 妻入, 平入の違いは家屋規模, 平面形式の何れにも求め 難いといえる。

また前節で検討した妻入, 平入別の平面上の諸特徵, 例えば居室上手の諸装置の奥行幅, 座敷飾りの設置状況 の推移, 柱間装置などに, いずれも妻入，平入を区別し うる特徴は認め難い。平面構成上も, 両町家は互いに区 別されるべき固有の特性を備えない。

次に, 構造とその発展過程について妻入と平入を比較 し検討する。 


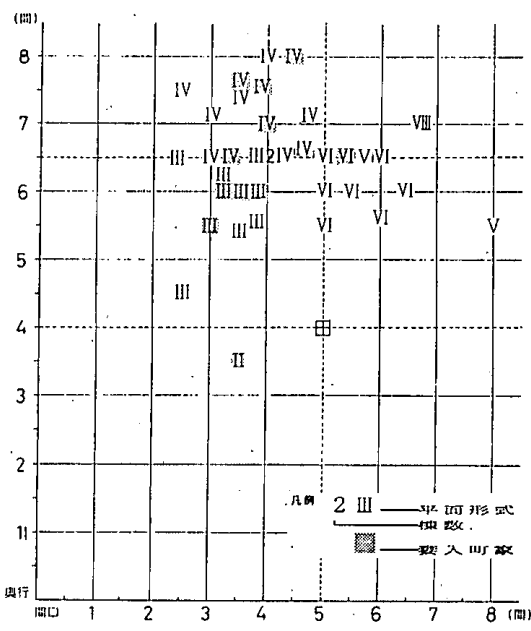

図一18 平面形式と家屋規模相関図

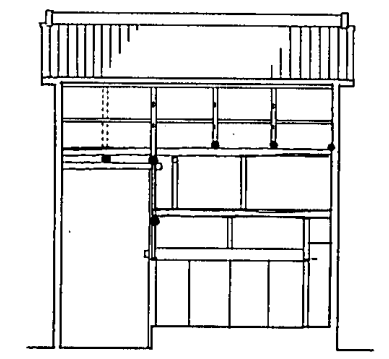

図一19 犬石秀夫家住宅 (平入) 析行復原断面図

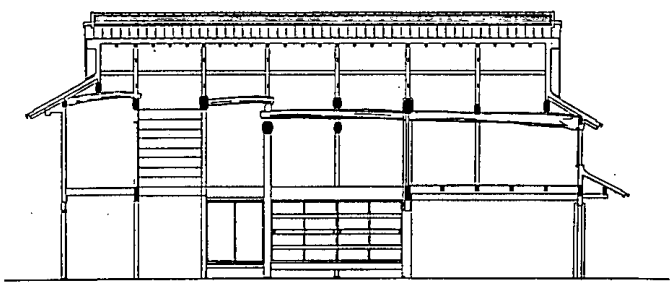

図一20 吉田喜一家住宅 (妻入) 桁行復原断面図

例えば犬石家住宅（平入）の構造（平入 b 型）は， その桁行断面（図一19）が，実は妻入の吉田家住宅（妻 入 B 型) の梁行断面（図一5 参照）と，梁組や小屋組な どに強い類似性が認められる。吉田家住宅の析行断面(図 -20）も犬石家住宅の梁行断面（図一11 参照）之同様 の構成をもつ。従って, 平入 $\mathrm{b}$ 型と妻入 $\mathrm{B}$ 型とは共通 の構造形式であるとみなせ，この場合平入と妻入の違い は，極論すれば単に屋根の架け方の相違であるといって も過言ではなかろう。その意味で犬石家住宅は, 妻入と の構造上の類似性を示す平入の遗構例として注目され る。

杉森家住宅（平入 a 型）も，犬石家住宅よりやや簡素 な形式ながら，その構成は妻入町家に通じる。

船越家住宅に代表される平入 $\mathrm{d}$ 型は，長い梁行材を 受ける析行梁がない点が平入 $\mathrm{a}$ 型と異なる。この析行梁 は妻入では小屋梁に相当する構造材であるから，この部 材の消滅は妻入之の構造上の関連性が薄くなったことの
指標となろう。しかしながら，なお残された梁行梁を妻 入との関連性の痕跡と見なすことは許されよう。

このように平入の構造は, $\mathrm{b}$ 型を始め $\mathrm{a}$ 型, $\mathrm{d}$ 型にい ずれも妻入との関連が認められた。これら妻入の構造を 備える平入町家の特質から, 平入町家の祖形は妻入に求 めうると考えられる。

平入 $\mathrm{b}$ 型の妻入之の強い類似性は, 併せて $\mathrm{b}$ 型が $\mathrm{a}$ 型に先行する（遺構年代は逆順するが）平入構造の古形 式と見なしうる可能性を示すとは言えまいか。恐らくは $\mathrm{b}$ 型形式の古い遺構はすでに現存せず，例えば $\mathrm{c}$ 型や $\mathrm{d}$ 型が成立した後になお a 型町家が建て続けられているこ とからも，b 型の犬石家住宅は，a 型（杉森家住宅）成 立後に建てられた，古形式を強く墨守した保守性の強い 遺構である可能性を指適しておきたい。

一方, 平入 $\mathrm{c}$ 型（野田家住宅, 他）は, $\mathrm{a}, \mathrm{b}, \mathrm{d}$ 型の 何れとも異なる構造形式であり, 妻入との構造上の関連 が認め難い。また $\mathrm{c}$ 型は年代的には $\mathrm{a}, \mathrm{b}$ 型に続き早く

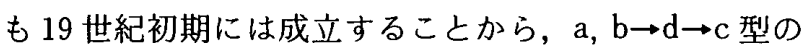
ように類似の構造形式の変化の結果として $\mathrm{c}$ 型を位置付 けることも難しい。つまり，野田家住宅では平入独自の 構造形式が成立しているといえ，妻入の影響を早期に脱 した発展方向を示す遺構として注目されるのである。

以上, 平面, 構造について妻入, 平入相互の関係を検 討した。平面の上からは両者は特記すべき違いはなく， 同様の構成をもつことが分かった。構造も，両者には強 い類似性が看取された。しかも年代の古い構造形式ほど その傾向が顥著であり，平入が妻入と類似する構造に よって構成されていることは, 平入は妻入から派生して 成立したことを窥わせる。さらに，平入は妻入との関連 が認めにくい新たな構造形式を確立させることもわかっ た。

\section{6. 周辺地域の町家との比較}

始めに述べたように，園部町周辺には旧山陰道にそっ て京都から亀岡 (旧亀山城下町)，八木（旧園部藩領の 街道集落, 旧八木村), 園部を経て丹波町須知（旧亀山 藩領の街道集落, 旧須知村）などの町が点在し，いずれ も妻入と平入の町家が混在する, 園部旧城下と似た歴史 的町並を良く留めている（図一21）。とすればこれら周 辺地域の町家も, 当町町家の特に構造に特色付けられる 家屋形式を同様に備えているのであろうか。筆者は, 園 部と併せてこれら諸地域においても少数例ながら関連調 查を実施した (表一3)。当町の町家を, これら諸地域の 町家との比較において再考する。

亀岡においては, 既に林野全孝博士による調查研究が ある (以下林野論文と呼ぶ $)^{11)}$ 。この研究報告は, 残念 ながら梗概に留まり，具体的な変遷過程までは論じられ なかったものの，18当世紀前期に遡る遗構を含む古い町 
表一3 亀岡市, 八木町, 丹波町須知調查遗構編年表

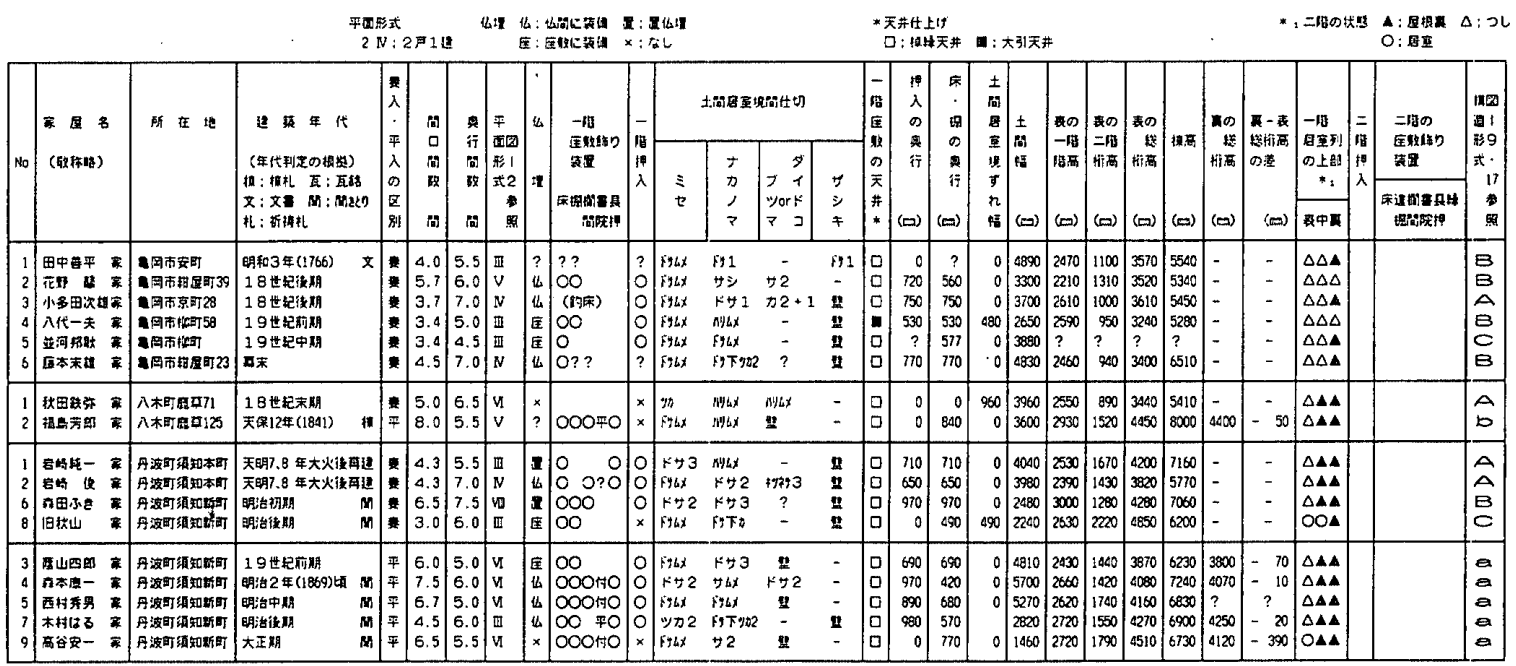

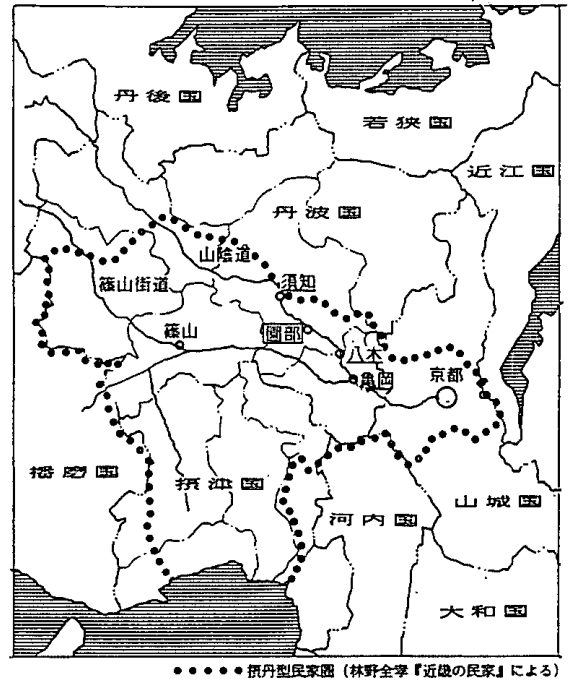

図一21園部旧城下町及び周辺町並位置図

家が数多く確認され, しかもその多くがその後建て替え られて現存しない点からも，その知見は重要である。

筆者は, 亀岡にて予備調查によって選んだ古い遺構を 中心に妻入町家数棟を調査した（平入町家については古 い遺構が発見できなかった）。その際には林野論文で紹 介された遺構の再調查を極力試みたが, 古町家ほど現存 せす，辛うじて明和 3 年 (1766, 系図より) の田中善平 家住宅の現存が確認された。この遺構は, 筆者の亀岡調 查における最古の遗構であり，かつ年代が判明している ことから, 亀岡の町並を代表する町家遺構の 1 例である といえる。

当家住宅は 1 列 3 間取り型の居室部の改造著しいが, 構造の主要部分を良く留める（図一22）。その構造を園 部の妻入遺構と比較すれば， 2 階はツシではあるが，そ の構成は園部の妻入 B 型と共通する。林野論文中の他の 妻入遺構もほぼ同様の構造をとることから, 園部と亀岡 の妻入町家は共通する構造をもつといえる。

八木町では，妻入町家の調查事例は 1 例に留まったが
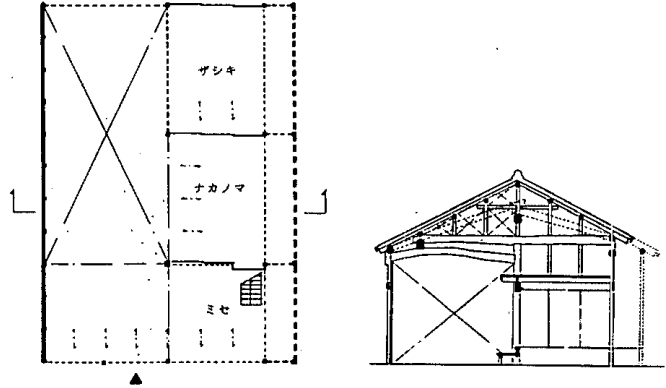

図一22 田中善平家住宅 (妻入) 復原平面図, 断面図
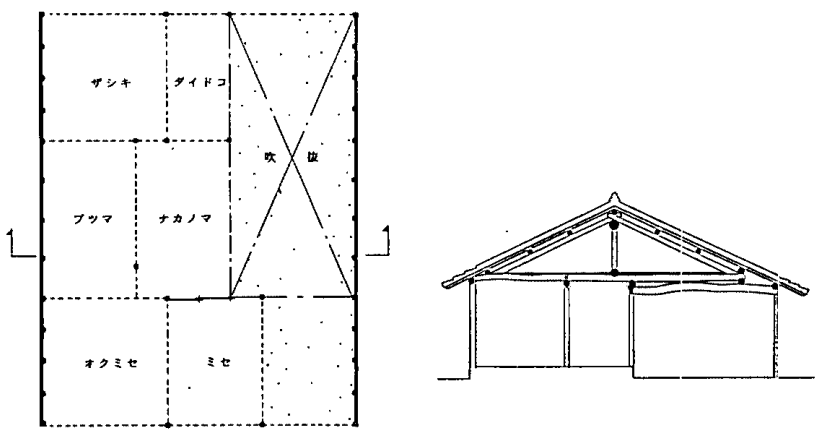

図一23 秋田鉄弥家住宅（妻入）復原平面図, 復原断面図

（秋田鉄弥家住宅，18 世紀後期，図一23）,やはり園部, 亀岡の妻入町家と同様の構成をより, 平入町家も福島芳 郎家住宅（天保 12 年, 1841, 棟札）は, 上手に落棟座 敷を持つが，それを除く構造は園部町の犬石家住宅の構 造形式 (平入 b 型) と良く似ている $(\text { 図一 } 24)^{12) 。}$

丹波町須知では，妻入（4棟), 平入（ 5 棟）ほほ同 数の調查を行なった。妻入である岩崎純一, 岩崎俊両家 住宅は天明大火後の再建と伝えられ，形式上もほぼその 頃と見なせるため, 須知における現存最古の遺構と思わ れる。両者は平面, 構造ともに園部の妻入町家と類似し （図一25），特に構造は園部の妻入 $A$ 型に相当する。し かも, その後 B型 (森田ふき家住宅, 明治初期), C型 (旧 

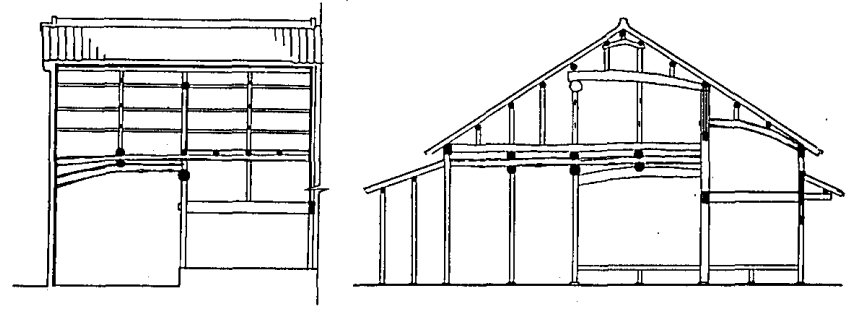

図一24，福島芳郎家住宅 (平入) 復原断面図
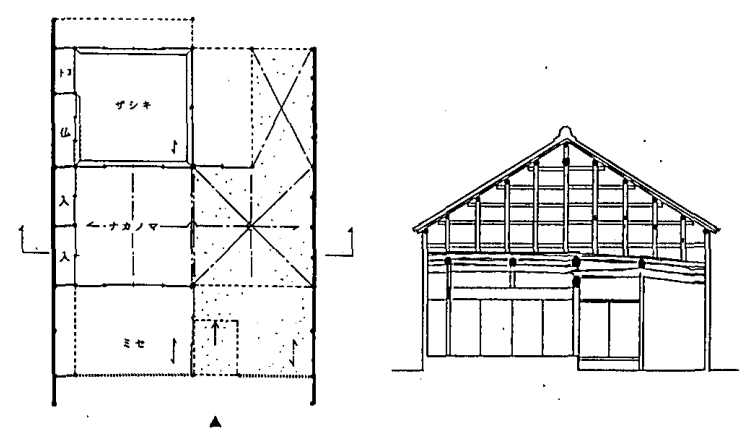

図一25 岩崎純一家住宅 (妻入) 復原平面図, 復原断面図

秋山家住宅, 明治後期) と, 遺構例は少ないが, 園部の 妻入遺構と同様の構造形式の発展を遂げることが看取で きる点も注目される (表一 3 参照)。

一方, 須知の平入では 18 世紀に遡る遺構は確認でき ず, 落山四郎家住宅 ( 2 列 6 間取り型, 19 世紀前期) を最古として, 森本康一家住宅 ( 2 列 6 間取り型, 明治 2 年頃, 図一26) 以下, 明治, 大正期の遺構が続く。こ れら平入の構造はいずれも園部の平入 $\mathrm{a}$ 型をとり, 妻入 と共に，平入も園部との類似性が確認されたといえる。

しかし, 須知の平入町家が大正期まで a 型の構造形式 を長く踏襲する点は, 園部の平入町家が 19 世紀中期に 既に $\mathrm{c} ， \mathrm{~d}$ 型形式を主流とすることと異なる。しかも裏 析高に目立った変化が認められず，19 世紀前期の低い 析高を維持し続け， 2 階がミセ上部のみに限られる点も， 明治初期に 2 階座敷が成立する園部之比較すれば保守的 である。これらは, 園部に対する須知の町家の地方差と して併せて指摘しておかなければならない。

以上, 旧山陰道に沿って園部旧城下町之隣接する各町 並の町家遺構を概観した。いずれの地域も妻入と平入が 混在し,これらの町家は平面を始め; 特に構造面で園部 城下の町家と強い共通性が確認された。従って, 換言す れば, 園部旧城下町の町家形式は, 旧丹波国の山陰道沿
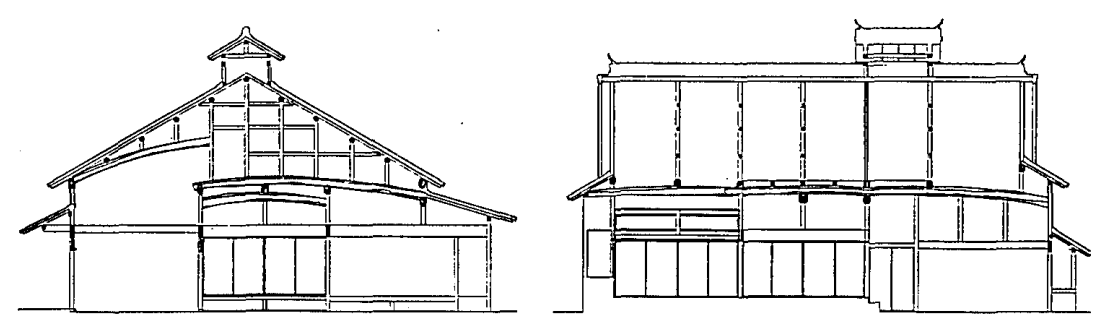

図一26．森本康一家住宅 (平入) 復原断面図
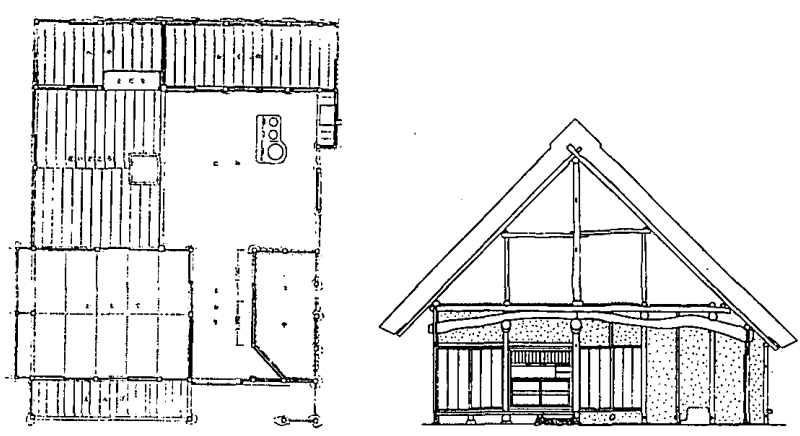

図一27旧岡花家住宅竣工平面図, 断面図「同家住宅移築修理 工事報告書」より

いの町並に共通する地方形式として位置付けることが許 されよう。

\section{7. 周辺農家との関連}

園部城下の町家形式が周辺の町並をも含む広域の地方 的形式であるならば，その成立を検討するためには，さ らに周辺農家との関係が問われなければならない。

始めに述べたが，旧丹波国を始め，攝津，山城の一部 は既往の民家調查により提丹型農家の分布圈であること が明かとなっている ${ }^{13)}$ 。園部を始め, 本稿で取り扱った 各町並に近在する摄丹型農家の代表的遗構としては, 丹 波地方における摄丹型農家の最古と考えられる旧岡花家 住宅（重文, 旧所在地：船井郡瑞穂町質志）があげられ よう(1)(図一27)。当家住宅を始めとする摂丹型農家は, その古形式が茅草妻入で表側に座敷を配する 1 例 3 間取 り型縦割り平面とし（旧岡花家住宅は土間裏手にも小室 を設ける)，さらに図一27に示す構造に主たる特徵があ る。

これら諸特徴のうち縦割り平面については, 町家に とってこの種の平面形状は, 当地域に限らずむしろ一般 的であろうことから，そのまま摄丹型農家に䌘るとは考 えにくい。また居室配列も, 園部では寛延 4 年 (1751) の片山弘家住宅が既に居室最奥に座敷を設けているし， 亀岡では享保 9 年 (1724, 棟札) の旧福井孝治家住宅に も同様の居室構成が成立していることから ${ }^{15)}, 18$ 世紀 前期に遡っても, 平面の上からは摂丹型農家との関連は 判然としない。町家平面の成立過程を求めるには, 恐ら く近世前期に遡る必要があろう。

この点では, 17 世紀に遡る古い町家遺構に恵まれた 奈良盆地の町家において，四間取り農 家之同様の平面構成から座敷を最奥に 配する町家独自の平面の成立が, 構造 の変化より著しく先行して認められる こと ${ }^{16)}$ 考え合わせると, 当地域で は 18 世紀前期以前の遺構が現存しな い以上, 平面の上で摂丹型農家との関 連は明らかにし難い。 

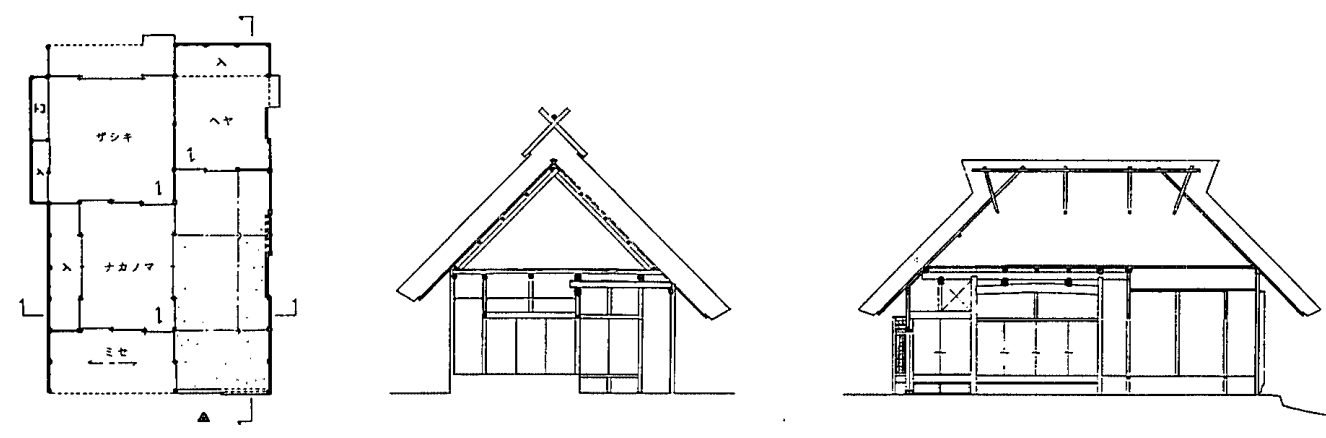

図一28 中川平六家住宅 (妻入) 復原平面図, 復原断面図

従って当該町家と摄丹型農家との接点は，妻入を主体 とする町並であることと, 構造の類似性に求めるべきで あろう。すなわち, 各町並ともに妻入町家が平入町家に 先行して確認され, 妻入が相対的に平入より古いこと。 かつ古い町家ほど摄丹型農家との構造の類似性が強い。 具体的には, 妻入 $\mathrm{A}$ 型あるいは $\mathrm{B}$ 型の構造形式は, 茅茸 と瓦荤の違いによる小屋組の違いを除けば, 搨丹型茅荣 妻入農家の構造之類似し, しかもこの構造は摄丹型特有 であることから, 当該町家の祖形式は摂丹型農家以外に は求め難いのである゙7)。

しかしながら，当地域の町家の祖形式と提丹型農家と の関係を具体的に検討するには, 城下町あるいは街道町 の成立期にまで遡った考察が必要となろう。園部城下で は，遺憾ながらこのような史料に恵まれず，その形成過 程は冒頭に述べた程度しかわからない。亀岡（旧亀山） 城下町については, 城下の建設に際し, 龟山城周辺の 9 ケ村がそのまま城下町に編成替えされたことにより成立 したと考えられている ${ }^{18}$ 。しいも城下は，その後独立し た町政をとりながらも，その経済基盤は農業を主とする ものが多いため, 旧郷村制の伝統が長く残り，新しい町 制と旧郷村制の二重形態（例えば，古世村分横町，追分 村分北町などの呼び方にも窥える) が続いた。当城下に おける町家遺構の摂丹型農家との関連性は, 当城下に先 行する農村集落を母体とする成立過程に求めることがで きそうであり，摂丹型農家を祖形として町家が成立した 可能性が強い。

ところで,これまでとりあげた町家の調査遺構は全て 瓦蒀であるが，それは園部，亀岡，須知の町並に茅荤町 家がもはや残存しないためである。しかし, 昭和 40 年 度調查による前記林野論文では茅苗の妻入町家が数棟調 查され，いずれもみな摂丹型農家と同様の構造をもつこ とが確認されている。また,これらのなかには, 当時瓦 莫妻入最古の遺構（旧福井孝治家住宅, 享保 9 年）より も古い茅茸妻入遺構（旧松波小春家住宅）が発見されて いることからも, 瓦直が普及する以前の刍岡の町並は茅 苜の町並であったと推察されるし, 他の集落も恐らく同 様であったであろう。

筆者は, 園部周辺の街道沿いに茅莫町家を数棟求めて
調查した。図一28 は篠山街道沿いの茅惪妻入町家の一例である (中川平六家住宅, 1 列 3 間取り型, 幕末頃, 龟岡市東本梅町 $)^{19}$ 。建築年代は異なるものの, 構造は 林野論文における刍岡の旧茅荤妻入町家と同じであり， かつ摄丹型農家に特有に構造である。このよう々事例加 らも, 瓦蒀町家に先行し, 摂丹型農家の構造を受け継ぐ 茅蒀妻入町家の構造が，瓦莫構造にそのまま踏毅された ものと推測されよう。

このように考えるとき, 園部城下の平入構造の 1 類型 である平入 c 型（野田家住宅, 他）は, 妻入とゆ構造上 の関連が認められる平入 $\mathrm{a}, \mathrm{b}, \mathrm{d}$ 各型とは区別され，ま た須知の平入町家の発展過程では大正に至ってもこの種 の構造形式が確認されない事実なども勘案すれば，園部 の平入町家の発展過程を特徵付る構造形式として注目さ れる。

平入 $\mathrm{c}$ 型の母屋までの通し柱と胴差による構成は，平 入だけに認められることと合せて，例えば京都の町家構 造との類似も窥われることから, 京都などの町家形式の 影響が可能性として指摘できよう。しかし，現在のとこ ろ, 京都亡の水運等による頻繁な物資の交流は確認され るものの ${ }^{20)}$, 京都からの町家建設にかかわる技術導入な ゼ具体的な影響関係は史料的制約から明らかにし難い。

この問題は, 京都あるいは大阪近在の町並における町 家形式の形成の解明において重要であるだけに，筆者の 今後に課せられた課題としたい。

\section{結 語}

以上, 園部旧城下町における町家遗構の特徵と発展過 程について, 構造の発展を中心に妻入, 平入の違いに注 目しつつ, 近隣地域の町家,さらには周辺農家との関係を も含めて考察した。以下にその結果を要記し, まとめと する。

（1） 妻入町家は，平入町家より相対的に古く，その構 造は，遺構年代が溯るほど摂丹型農家に類似することか ら, 当城下の町家の祖形式は周辺の提丹型農家である可 能性が強い。

(2) 同様に平入町家も, 妻入との構造上の頑似から, 妻入町家から派生したものと考えられる。 
（3）従って城下の町家は，妻入，平入共に摂丹型農家 の影響下で発展したといえる。

（4）このような園部旧城下の町家は，近在の亀岡，八 木, 須知など，山陰道に沿う各町並の町家遺構とも共通 することから，園部城下の町家はこれら諸地域を含む広 域の地方形式と考えることができる。

（5）妻入之平入の違いは，平均的な間口幅の範囲（約 6 間以下）では平面，規模，平面構成の諸特徵も含めて 殆ゼ認められず，平面の上では妻入，平入は区別できな い。

（6）従って 18 世紀以前の古い町家では，妻入，平入 の違いは平面の共通性や構造の類似性により，極論すれ ば単に屋根の架け方の違いによる外観のみの違いである ともいえよう。

（7）平面形式は妻入，平入共に 1 列型が量的主流を 占め, かつ古い遺構の多くはこの形式である。大型の 2 列型町家は主として平入町家であり，特に19 世紀中期 以降の町家に多い。

（8）また，18 世紀の町家の多くはナカノマが座敷よ り広く，ナカノマが居室の中心であることが窺える。

（9）それに対して19 世紀以降の町家は，十力ノマよ り座敷を大きくとり，それに伴い1列型町家では土間居 室境で居室を食い違える遺構例が多く認められる。また 座敷飾りも立派になり, 特に幕末以降, 書院座敷化が顕 著に進む。

（10）構造面での 18 世紀後期以降の発展過程は，妻入， 平入共に摄丹型農家構造の簡略化を辿るが，平入町家は 摄丹型の構造とは関連のない独自の構造形式を確立す る。

（11）この間，平入町家は漸次高まる裹析高とパラレル に連動しつつ 2 階の利用が高まり, 明治に入ると 2 階居 室が成立する。

（12）このような園部旧城下の平入町家の発展は，18 世紀以来の古い構造形式を長く踏襲し，かつ 2 階形成も 認められない須知の平入町家と比較したとき，掑丹型民 家の影響下における町家の内発的な構造的変化だけでは 考えにくい。例えば，当時園部城下と交流の多かった京 都の町家形式などとの外的な要因も想起されるが, 本稿 ではその可能性の指摘に留めた。

\section{謝 意}

本稿を草するに当たっては，終始林野全孝博士より親 身なるご指導を受けた。家屋調查においては, 園部町教 育委員会（高木茂教育長）加多大の御協力を得，亡り わけ調査依頼に際しては西田信夫先生に全面的にご支援 頂いた。また，田中耕一郎氏には史料調查において何か 之便宜を計っていただき，並河康夫氏には，大工技法に 関する貴重なご教授を受けた。さらに，家屋調查は，林
野博士を始め京都府立大学住居学科の大学院生, 専攻生 の多数の協力を受け，なにより町家各家々にお住まいの 方々に全面的な調査協力を得て実施された。合せて深く 感謝の意を表するものである。

注

1）大場 修，ほか「園部城下町の町家について その1」 「同 その2)」

「日本建築学会学術講演梗概集」昭和 62 年

2）京都府立大学桂川流域学術調查の一環として町家調查を 実施し, 昭和 63 年に林野博士と連名で「園部旧城下町の 町家に関する調査研究」と題し，同調査報告を行なって いる。 京都府立大学「桂川流域学術調查報告」昭和 63 年

3）竹岡 林「丹波園部城」

4）出野 明文書, 「園部町史」史料編 II 巻, p. 156, 昭和 56 年, 所収

5）土仲高明氏所藏

6）前揭 3)

7）吉田 證「丹波の歴史」, ほか

8）【園部町史」史料編第 II巻, p. 425, 所収

9）園部町教育委員会所蔵

10）「園部町史」史料編第 II 巻, p. 487, 所収

11）林野全孝「龟岡における町屋建築の変遷と特徵」「日本建 築学会論文報告集」昭和 41 年 10 月

12），福島家住宅は前揭 11）にも調查がされている。今回はさ らに新たな断面図 2 面を作成した。

13）青山賢信 ほか「能勢地方における民家平面の変動過程」 「日本建築学会論文報告集」第 69 号 昭和 36 年 10 月 日本民家集落博物館「能勢の民家」日本民家集落博物館 䲃報 II, 昭和 40 年 永井規男「摂丹型民家の形成」「日本建築学会論文報告集」 第 251 号, 昭和 52 年 1 月 京都府教育委員会 『京都府の民家」第六冊，昭和 45 年 京都府教育委員会「京都府の民家」第七冊，昭和 48 年, 他

14）大本本部建設事務局「重要文化財旧岡花家住宅移築修理 工事報告書」昭和 49 年

15）前揭 11）林野全孝「亀岡における町屋建築の変遷と特徵」

16）拙稿「奈良盆地における町家の発展過程一架構形式の変 容を通して一」

「日本建築学会計画系論文報告集」 403 号，平成元年 9 月

17）この指摘は林野博士の程岡論文（前揭 11）にて既になさ れているが，本稿はその関係をより明確にしえたといえ よう。

18）【亀岡市史」中巻, p. 204, 昭和 40 年

19）なお，当家住宅の平面は 1 列 3 間取り型で，表にミセを 設け町家としての構成を備えているが, 土間裏手に部屋 を設ける構成は旧岡花家住宅と通する点が注目される。

20）園部城下は大堰川の舟筏によって, 京都と水陸の交通路 に惠まれた。

「園部町史】史料編第IV巻, p. 25，昭和 50 年

（1989 年 8 月 10 日原稿受理, 1990 年 4 月 7 日採用決定） 